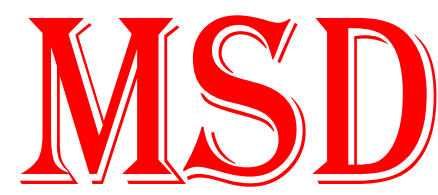

Medical Science and Discovery ISSN: 2148-6832

\section{Evaluation of anemia frequency and etiologies in hospitalized patients in a tertiary pediatrics clinic}

\author{
İlhan Gürsoy ${ }^{1}$, Emine Türkkan ${ }^{1}$, Hüseyin Dağ ${ }^{1,2} *$ \\ 1 Dep of Pediatrics, University of Health Sciences, Prof. Dr. Cemil Taşcıŏlu City Hospital, Istanbul, TR \\ 2 Dept of Pediatric Basic Sciences, Istanbul University, Institute of Child Health, Adolesance Health, Istanbul, TR \\ * Corresponding Author: Hüseyin Dağ E-mail: huseyindag2003@gmail.com
}

\section{ABSTRACT}

Objective: Anemia, which is a public health problem on a global scale, continues to maintain its importance in pediatric patients. There are few studies on the prevalence of anemia in hospitalized children. This study was conducted to evaluate the prevalence and etiologies of anemia in hospitalized pediatric patients.

Material and Method: This is a cross-sectional epidemiological study. The study group consists of 1000 patients between the ages of 6 months and 18 years who were hospitalized in the Department of Pediatrics of Prof. Dr. Cemil Tascioglu City Hospital. The data of the patients were reviewed retrospectively. The SPSS 22.0 program was used for statistical analyzes and calculations and $p<0.05$ was accepted for significance.

Results: Of the patients included in the study, 569 (56.9\%) were male, and $431(43.1 \%)$ were female. In the study, the number of patients with anemia was $276(27.6 \%)$, and among those $151(26.5 \%)$ were male and $125(29.0 \%)$ were female. The highest rate of anemia in different age groups was in infancy, with $32.3 \%$.

The number of patients with iron deficiency anemia was $121(43.8 \%)$, anemia of chronic disease was $42(15.2 \%)$, anemia of acute inflammation was 41 (14.9\%), and anemia due to B12 deficiency was $31(11.2 \%)$. It was determined that patients with anemia had a longer hospital stay than those without anemia. Moreover, the hospitalization period of patients with anemia of chronic disease was longer than those with iron deficiency anemia.

Conclusion: Anemia is an important problem in hospitalized children as well as in the general population. Iron deficiency is the most common etiology of anemia in hospitalized patients in the pediatric clinic similar to the general population. The hospitalization period was found to be significantly longer in anemic patients than in nonanemic patients. During hospitalization, children should be monitored for anemia and this duration of stay should be regarded as an opportunity to combat anemia or to provide necessary micronutrient or nutritional support to socioeconomically disadvantaged groups.

Keywords: Anemia, iron deficiency, pediatrics, hospital

\section{INTRODUCTION}

Anemia, which is considered a public health problem on a global scale, is defined as a decrease in hemoglobin or hematocrit levels below two standard deviations according to age, race, and gender (1-3). Worldwide, it is estimated that approximately one-quarter of the world's population has anemia, and this prevalence is higher in developing countries. Although anemia is common, the prevalence of anemia may vary according to the development level of countries. The anemia prevalence was reported as $9.1 \%, 25.7 \%$, and $42.8 \%$ in high, middle, and low-income countries, respectively. The 2015 WHO report, derived from the global prevalence of anemia in 2011, showed that the highest frequency $(42.6 \%)$ was in children compared to other age groups in the world (4). Despite a decline in prevalence globally, total cases of anemia rose from 1.42 billion in 1990 to 1.74 billion in 2019. The greatest burden of anemia was found in west and central sub-Saharan Africa and South Asia, while the highest prevalence of combined anemia (39.7\%) was found in children under the age of five (5). When the anemia causes are examined according to etiologies, iron deficiency anemia is the leading one. It is estimated that around $50 \%$ of anemia cases are attributed to this micronutrient deficiency, however, this rate likely 
varies considerably between regions and countries. Other causes of anemia include other micronutrient deficiencies such as folic acid and vitamin B12 deficiencies; the presence of infectious diseases and genetic hemoglobin disorders (6, 7).

In epidemiological studies, it was found that anemia is associated with impaired neurocognitive outcomes, including learning difficulties, corrupted memory and processing speed, and emotional instability. Iron, folic acid, and vitamin B12 are essential for brain development and function. In general, a deficiency of these micronutrients results in decreased myelin production by altering gene and protein profiles, which can regulate central nervous system development processes. Impaired synaptogenesis and neural repair may lead to delays in brain development or dysfunction (8-11).

There are different anemia rates among hospitalized children in line with the sociocultural level and developmental state of countries. The presence of anemia augments the treatment process and the risk of hospital stay (4). Our aim in this study is to evaluate our hospitalized patients in terms of the prevalence of anemia and to discuss possible complications of this condition with the precautions that can be taken in this regard.

\section{MATERIAL and METHODS}

This study was performed on 1000 children between the ages of 6 months and 18 years who were hospitalized in the Department of Pediatrics of Prof. Dr. Cemil Tascioglu City Hospital between 01.03.2019 and 01.03.2020 and meet the inclusion criteria of the study. The patients with missing data were excluded from the study. This study is a cross-sectional, retrospective epidemiological study. Patients younger than six months and older than 18 years of age, and patients hospitalized in neonatal intensive care, pediatric intensive care, and/or pediatric hematology wards were not included in the study. The patients were divided into three groups according to their ages; those aged 6-24 months were included in the infancy period, those aged 3-9 years were included in the childhood period, and those aged 10 -18 years were included in the adolescence period (12). Demographic characteristics of the patients, diagnosis of hospitalization, duration of hospitalization, presence of anemia, transfusion information, presence of chronic diseases, complete blood count parameters at admission and discharge, ferritin, vitamin B12, foliate, C-reactive protein levels were recorded from the patient files. Anemia was diagnosed based on the reference values (13). This study was carried out in accordance with the Helsinki declaration, after the approval of the clinical research ethics committee of Cemil Tascioglu City Hospital (the date 26/01/2021 and number 26).

Statistical Package for the Social Sciences (SPSS) program was performed to evaluate and analyze the research data. Numerical data were reported as mean (standard deviation) and median (minimum-maximum); while the categorical data were given as numbers and percentages. KolmogorovSmirnov and Shapiro-Wilk tests were used to determine the conformity of the data to the normal distribution. Parametric tests were performed if the data met the necessary assumptions, and non-parametric tests were used if they did not. The statistical significance was set at $\mathrm{p}<0.05$.

\section{RESULTS}

In the study, which was carried out to determine the frequency and the etiology of anemia in hospitalized children, 1000 patients (569 boys and 431 girls) were examined and their demographic characteristics are summarized in Table 1.

While anemia was not detected in 724 (72.4\%) of 1000 patients included in the study; anemia was present in 276 $(27.6 \%)$ patients. Accordingly, the prevalence of anemia was found to be $27.6 \%$ in patients hospitalized in our clinic. The prevalence of anemia was found to be $26.5 \%$ in boys and $29.0 \%$ in girls.

The rate of anemia was $54.7 \%$ male and $45.3 \%$ female. According to the analysis for the etiology of anemia by gender, $63.6 \%$ of patients with iron deficiency, $52.4 \%$ of patients with anemia of chronic disease, $51.2 \%$ of patients with anemia of acute inflammation, and $43.1 \%$ of patients with other etiologies were male and there was a statistically significant difference between the genders regarding the etiology of the anemia (Table 2).

Of 276 patients with anemia, $121(43.8 \%)$ were having iron deficiency anemia, $42(15.2 \%)$ were having anemia of chronic diseases, $41(14.9 \%)$ were having anemia of acute inflammation, and $31(6.9 \%)$ were having B12 deficiency anemia (Table 3).

In addition to being the most common cause of all anemia cases, iron deficiency anemia is the leading cause of anemia with $50.3 \%$ in infancy, $23.1 \%$ in childhood, and $32.5 \%$ in adolescence.

As summarized in Table 4, 849 (84.9\%) of the patients did not have a chronic/concomitant disease, while a concomitant chronic disease was detected in $151(15.1 \%)$ of the patients. Among these diseases, epilepsy was the most common with a $24.5 \%$ prevalence.

According to the analysis performed to compare the length of stay in the hospital according to the etiology of anemia, the average length of stay (minimum-maximum) of patients diagnosed with iron deficiency was 3 (2-23) days; it was 6 (221) days in patients with anemia of chronic disease, 4 (1-25) days in patients with anemia due to acute infection, 4 (2-15) days for anemia due to B12 deficiency, and 4 (2-23) days for other etiologies of anemia.

There was a statistically significant difference between the groups regarding the hospitalization periods $(p<0.001)$. When anemia of chronic disease was compared with iron deficiency, a statistically significant difference was found, prolonging the length of hospital stay. No statistically significant difference was found in the pair-wise comparisons of the other groups (figure 1).

As seen in Figure 2, when the duration of hospitalization is compared according to the presence of anemia, the average length of stay in the hospital for patients with anemia (minimum-maximum) was 4 (1-25) days, and the average duration of hospitalization for patients without anemia (minimum-maximum) was 3 (1- 14) days and there was a significant difference between the groups $(\mathrm{p}<0.001)$. 
When the etiologies of anemia were compared according to the erythrocyte suspension transfusion requirements, the highest transfusion requirement was observed in patients with anemia of chronic disease with a rate of $23.8 \%$.

As seen in Table 5, the difference between the groups was statistically significant $(\mathrm{p}=0.003)$.

Of the patients included in the study, $384(38.4 \%)$ were in infancy, $451(45.1 \%)$ were in childhood, and $165(16.5 \%)$ were in adolescence. The prevalence of anemia in infancy was $32.3 \%$, it was $24.8 \%$ in adolescence, and $24.6 \%$ in childhood. According to the analysis performed to compare the presence of anemia by age groups, there was a statistically significant difference between the groups. According to the pair-wise comparisons of the groups, the difference between infancy and childhood was statistically significant in that anemia was more common in infancy. However, the difference between infancy and adolescence and between childhood and adolescence was not statistically significant.
According to the analysis performed to compare the hospitalization and discharge hemoglobin levels of the patients (patients with erythrocyte suspension were not included in the analysis, $n=307)$ the mean ( \pm standard deviation) admission hemoglobin level was $11.71( \pm 1.63) \mathrm{g} / \mathrm{dl}$ and discharge hemoglobin (standard deviation) was 11.50 $( \pm 1.54) \mathrm{g} / \mathrm{dl}$, and a statistically significant difference was found between the two groups $(\mathrm{p}<0.001)$. Accordingly, the hemoglobin measurement of the patients at discharge was $0.21 \mathrm{~g} / \mathrm{dl}$ lower than the hemoglobin level at admission. The mean ( \pm standard deviation) hospitalization hemoglobin of the patients in infancy was $10.98( \pm 1.30)$ and the mean discharge hemoglobin was $10.70( \pm 1.25) \mathrm{g} / \mathrm{dl}$, and the difference was statistically significant. The mean ( \pm standard deviation) hospitalization hemoglobin of the adolescent patients was $12.92( \pm 1.96)$ and the mean ( \pm standard deviation) discharge hemoglobin was $12.69( \pm 1.88) \mathrm{g} / \mathrm{dl}$, and the difference was found to be statistically significant $(\mathrm{p}<0.001)$.

Table 1. Demographic features of the study participants

\begin{tabular}{|c|c|c|}
\hline Feature & Number (n) & Percentage (\%) \\
\hline Gender & & \\
\hline Male & 569 & 56.9 \\
\hline Female & 431 & 43.1 \\
\hline Age groups & & \\
\hline Infancy period (6 months- 2 ages) & 384 & 38.4 \\
\hline Childhood period (3-9 years) & 451 & 45.1 \\
\hline Adolescence period (10-18 years) & 165 & 16.5 \\
\hline Total & 1000 & 100 \\
\hline
\end{tabular}

Table 2. Comparison of the etiology of the anemia between genders

\begin{tabular}{lcccc}
\multicolumn{1}{c}{ Etiology } & Male n (\%) & Female n (\%) & Total n (\%) & p \\
\hline Iron deficiency & $77(63.6)$ & $44(36.4)$ & $121(100.0)$ & \\
Chronic diseases & $22(52.4)$ & $20(47.6)$ & $42(100.0)$ & \\
Acute infections & $21(51.2)$ & $20(48.8)$ & $41(100.0)$ & 0.043 \\
Others & $31(43.1)$ & $41(56.9)$ & $72(100.0)$ & \\
Total & $151(54,7)$ & $125(45,3)$ & $276(100)$ & \\
\hline
\end{tabular}

Table 3. Anemia frequency and etiology

\begin{tabular}{lcc} 
Anemia etiology & Number(n) & Percentage(\%) \\
\hline Iron deficiency anemia & 121 & 43.8 \\
Anemia of chronic diseases & 42 & 15.2 \\
Anemia of acute inflammation & 41 & 14.9 \\
B12 deficiency anemia & 31 & 11.2 \\
Iron and B12 deficiency anemia & 14 & 5.1 \\
Chronic diseases and iron deficiency anemia & 5 & 1.8 \\
Foliate, B12, and iron deficiency & 5 & 1.8 \\
Idiopathic & 3 & 1.1 \\
Anemia due to acute hemorrhage & 3 & 1.1 \\
Foliate deficiency & 3 & 1.1 \\
Thalassemia Intermedia & 3 & 1.1 \\
Sickle cell anemia & 2 & 0.7 \\
Thalassemia Major & 2 & 0.7 \\
Hereditary Spherocytosis & 1 & 0.4 \\
Total & $\mathbf{2 7 6}$ & $\mathbf{1 0 0 . 0}$
\end{tabular}


Table 4. Chronic/concomitant disease

\begin{tabular}{lcc} 
Feature & Number (n) & Percentage (\%) \\
Concomitant disease & & 84.9 \\
\hline Present & 849 & 15.1 \\
\hline Absent & 151 & $\mathbf{1 0 0 . 0}$ \\
\hline Total & $\mathbf{1 0 0 0}$ & 24.5 \\
\hline Disease & & 13.2 \\
\hline Epilepsy & 37 & 10.6 \\
\hline Frequent asthma or bronchitis attacks & 20 & 7.3 \\
\hline Congenital cardiac disease & 16 & 6.0 \\
\hline Down Syndrome & 11 & 6.0 \\
\hline Cerebral Palsy & 9 & 5.3 \\
\hline Inflammatory bowel disease & 9 & 5.3 \\
\hline Hypothyroidism & 8 & 4.6 \\
Malignity & 8 & 3.3 \\
Celiac disease & 7 & 3.3 \\
\hline Tuberculosis & 5 & 3.3 \\
\hline Nephrotic Syndrome & 5 & 3.3 \\
\hline Autism Spectrum Disorder & 5 & 2.6 \\
\hline Chronic Liver diseases & 5 & 1.3 \\
\hline Factor 8 Deficiency & 4 & $\mathbf{1 0 0 . 0}$ \\
\hline Others & 2 & $\mathbf{1 5 1}$ \\
\hline Total & & \\
\hline & & \\
\hline
\end{tabular}

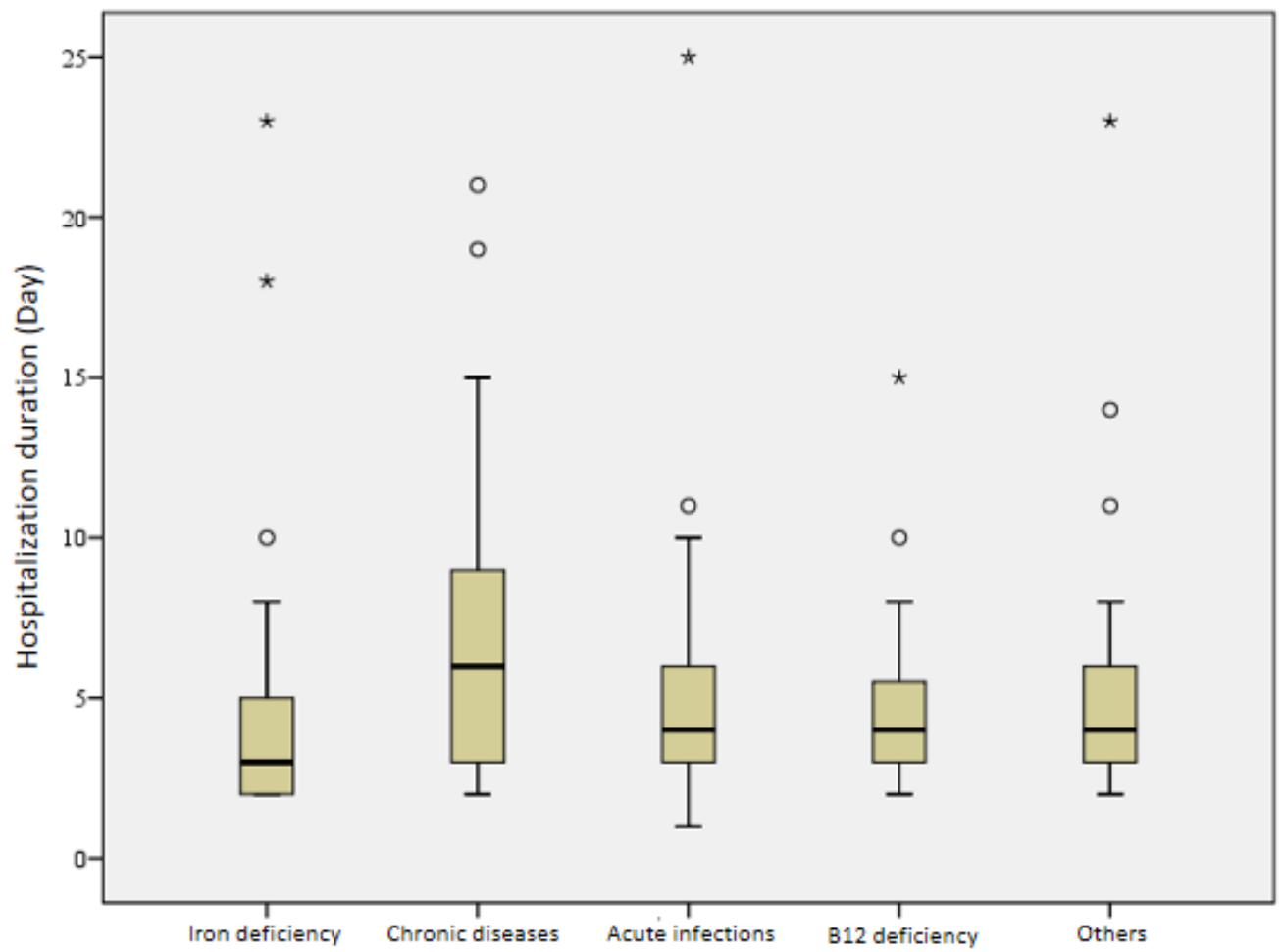

Anemia etiology

Figure 1. Duration of hospitalization regarding the anemia etiology 


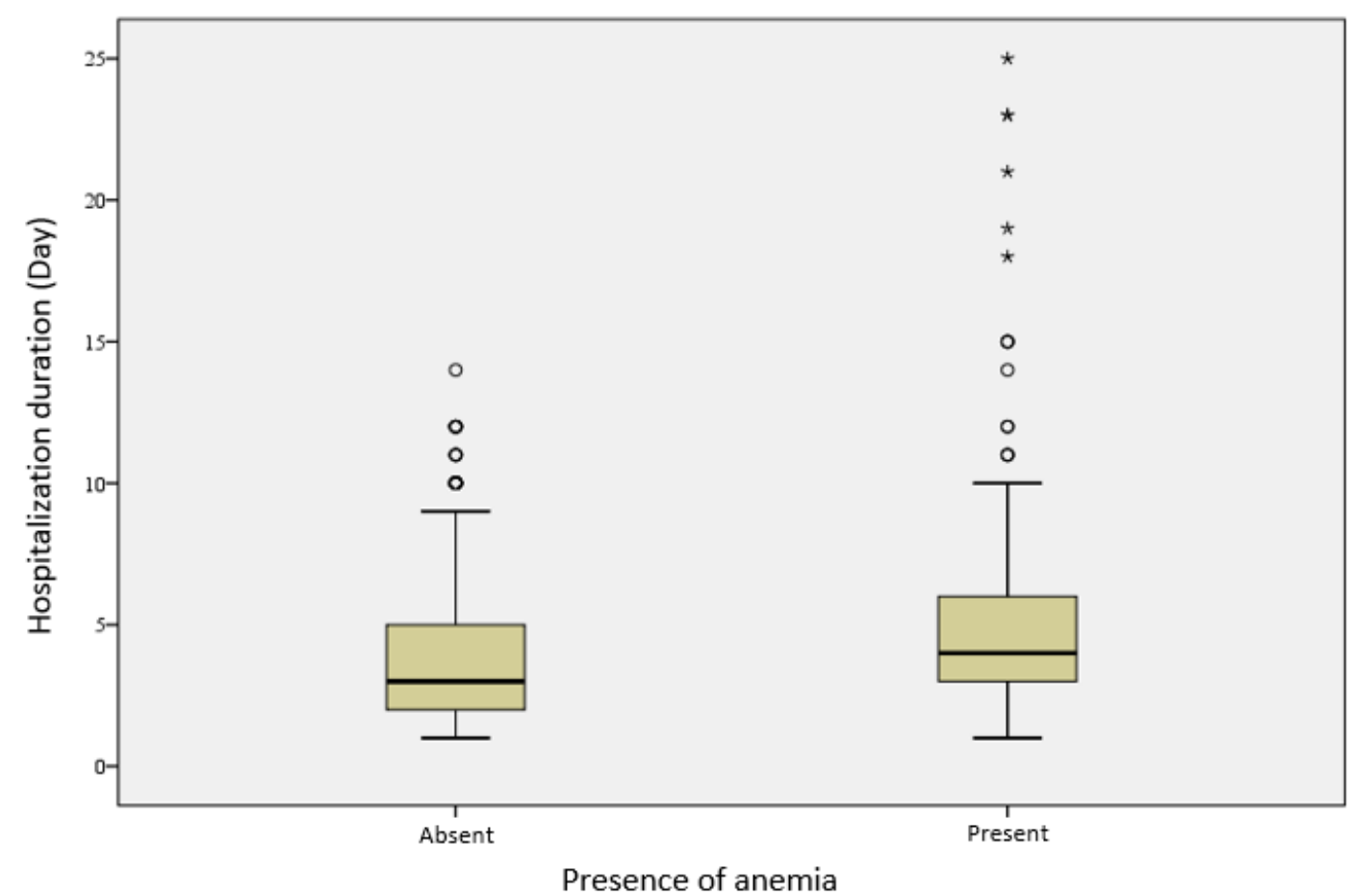

Figure 2. Hospitalization duration in the presence of anemia

Table 5. Comparison of erythrocyte suspension transfusion requirements according to the etiology of anemia

\begin{tabular}{lcccc} 
& \multicolumn{2}{l}{ Erythrocyte suspension requirements } & \\
Etiology & Absent $\mathrm{n}(\%)$ & Present $\mathrm{n}(\%)$ & Total $\mathrm{n}(\%)$ & $\mathrm{p}$ \\
\hline Iron deficiency & $115(95.0)$ & $6(5.0)$ & $121(100.0)$ & \\
Chronic diseases & $32(76.2)$ & $10(23.8)$ & $42(100.0)$ & 0.003 \\
Acute infections & $38(92.7)$ & $3(7.3)$ & $41(100.0)$ & \\
Others & $66(91.7)$ & $6(8.3)$ & $72(100.0)$ & \\
\hline
\end{tabular}

\section{DISCUSSION}

The general prevalence of anemia in the world is around $42.6 \%$. In our study, the prevalence of anemia was found to be $27.6 \%$. Salami et al. (15) found the prevalence to be $33.2 \%$ in a study conducted in hospitalized pediatric patients aged between 1 month and 12 years. The prevalence of anemia was found to be $62.3 \%$ in a study conducted on the African continent, (4). In Europe and similarly developed countries, the prevalence of anemia was around $15 \%$ which is lower (16). The prevalence of anemia in the world is in a wide range according to age groups and socio-cultural levels. Although the rate we found in our study included hospitalized patients, it is compatible with the general population values of the literature. The decrease in anemia in proportion to the level of development shows that access to micronutrients and other nutrients is a fundamental factor. As a matter of fact, in the study of Salami et al.(15), children with malnutrition encountered anemia 3.4 times more than those without malnutrition.

Anemia in childhood is most common between the ages of 6 months and 2 years (17). The higher prevalence of anemia in infants is mostly attributed to the inability to meet the increasing need proportional to the increasing growth rate (18). In our study, the prevalence of anemia in infancy was found to be $32.3 \%$ and higher than that of other age groups, in line with the literature.
Zuffo et al. (19) found the prevalence of anemia in children younger than 24 months to be $39.9 \%$. This rate was higher than other age groups, similar to our study. Sayar et al. (20) found the prevalence of anemia in the neonatal period to be $3.2 \%$ in their study conducted with healthy newborns and infants, while they found this rate to be $22.3 \%$ in the 6 thmonth control of the same children. As can be understood from the literature, we can say that this period is important in terms of micronutrient support.

Secondly, the highest frequency of anemia is seen in the adolescent age group (17). In our study, this rate was $24.8 \%$, and it was the period in which anemia was seen with the second frequency. In the study of Dugdale et al., this frequency was found to be $27 \%$ in developing countries and $6 \%$ in developed countries (21). In a study conducted in our country, this frequency was found to be $12.5 \%$ (22). The lower prevalence in our study may be due to the selection of our patient group from hospitalized patients. It can be thought that anemia is more common in this age group, which may be due to the increased muscle strength and growth in boys, and growth and menstruation in girls.

When all age groups were included in our study, $54.7 \%$ of the patients diagnosed with anemia were male. Similarly, Enawgaw et al. (4) found that $55.2 \%$ of the patients with anemia were male. 
This can be explained by the fact that anemia is more common in boys compared to girls due to rapid development in the pre-school period (23). On the other hand, in a study conducted by Salami et al.(15) in which they evaluated hospitalized patients, although anemia was more common in males, they could not find a statistical difference. Some studies are the opposite of this and found anemia more commonly in females $(24,25)$.

When patients with anemia were examined, the most common etiological factor was iron deficiency anemia with $43.8 \%$. In a study conducted by Çetinkaya et al. in hospitalized patients, they found the prevalence of iron deficiency anemia to be $61.6 \%$ (26). In a prevalence study conducted by Balci et al. in adolescent patients, they found the rate of anemia to be $5.6 \%$. Among all anemia, iron deficiency anemia was the most common (24). In the study of Silva et al., they found the prevalence of iron deficiency anemia to be $10.3 \%$, but in the same study, the rate of iron deficiency was found to be $37.4 \%$. In a study conducted on hospitalized children from Turkey, the frequency of iron deficiency anemia was found to be $16.5 \%$ (27). As can be seen, studies are reporting different frequencies. Iron is a very important micronutrient, especially in childhood age groups. Its deficiency causes iron deficiency and iron-deficiency anemia. After understanding the importance of this condition, countries started to give iron supplements in certain age groups as a part of preventive health services. As a matter of fact, as a part of this struggle since 2004, prophylactic iron supplementation has been applied to all infants from 4 months of age with the "Turkey as iron" campaign in our country. This treatment is applied free of charge until the age of 1 (28). Although positive results have been obtained with this treatment, unfortunately, we are still far from the target of reducing it to 5\% and below recommended by the World Health Organization. More education and nutritional support should be provided to socioculturally disadvantaged groups. However, patients who do not receive prophylaxis should be checked for anemia with certain follow-up programs. There are follow-up guidelines published for these controls in our country (29).

B12 deficiency anemia is another common nutritional anemia in developing countries, and it has been reported that it is more common especially in children and pregnant women (30). In studies conducted in regions with low socioeconomic status, the frequency of B12 deficiency has been reported to vary between $22-65 \%$ (31). Naiboglu et al. (27) found the frequency of B12 deficiency to be $51.5 \%$ in their study on children hospitalized due to lower respiratory tract infection. In our study group, the rate of patients with B12 deficiency anemia was found to be $11.2 \%$. When combinations of B12 deficiency with other etiologies are included, B12 deficiency anemia constitutes $18.1 \%$ of all anemia cases. B12 deficiency continues to be important in developing countries, especially due to nutritional deficiencies.

In our study, when the relationship between anemia and the length of stay of the patients was examined, a significant relationship was found, and the hospitalization period of patients with anemia was higher than those without anemia Salami et al (15) did not find any significant relationship between anemia and hospitalization periods. However, it is not easy to explain the hospitalization period only with anemia. It is obvious that this may change depending on the underlying disease and treatment processes. On the other hand, a significant correlation was found between the etiology of anemia and the need for transfusion of erythrocyte suspension during their hospitalization, and the group with the most frequent transfusion requirement was the patients with anemia of chronic disease. These patients may have had higher transfusion needs than non-hospitalized patients with iron deficiency due to their other accompanying health problems. The discharge hemoglobin levels of our patients who were not transfused were found to be lower than the hospitalization hemoglobin levels. Since our hospital is a tertiary center, we think that this situation occurs due to the hospitalization of patients who require more examinations and investigations.

Our study has some limitations. Since our study was retrospective, it was not possible to reach the socioeconomic data of our patient group, the information about whether the patients received iron prophylaxis, their dietary habits, and histories from the file information.

\section{CONCLUSION}

In conclusion, this study showed that anemia is an important problem in hospitalized children, iron deficiency anemia is the most common etiological cause in this group, as in the general population, and that the hospitalization period in anemic patients is longer than that of the non-anemic patients. During hospitalization, as in public health monitoring programs, children should be monitored for anemia and hospitalization should be seen as an opportunity to combat anemia or to provide necessary micronutrient or nutritional support to socioeconomically disadvantaged groups.

Author Contributions: IG, ET, HD: Concept, Data collection and/or processing, Analysis and/or interpretation, Literature review, HD: Writing, Revision

Financial \& competing interest's disclosure: The authors have no relevant affiliations or financial involvement with any organisation or entity with a financial interest in or financial conflict with the subject matter or materials discussed in the manuscript. This includes employment, consultancies, honoraria, stock ownership or options, expert testimony, grants or patents received or pending, or royalties.

Conflict of interest: The author declared no potential conflicts of interest with respect to the research, authorship, and/or publication of this article. This research did not receive and specific grant from funding agencies in the public, commercial, or not-for-profit sectors.

Ethical approval: The study was conducted according to the guidelines of the Declaration of Helsinki and approved by Local Ethical Committee.

\section{REFERENCES}

1. Gajjar R, Jalazo E. Hematology. In: Engorn B, Flerlage J, eds. The Harriet Lane Hand $\neg$ book. Philadelphia, PA: Elsevier Saunders; 2015:305-313

2. Baker R, Greer F. Clinical report: diag $\neg$ nosis and prevention of iron deficiency and iron-deficiency anemia in infants and young children $(0$ 3 years of age). Pediat $\neg$ rics. 2010;126(5):1040-1050. doi:10.1542/ peds.2010-2576 
3. Khan L. Anemia in Childhood. Pediatr Ann. 2018;47(2):e42-e7.

4. Enawgaw B, Workineh Y, Tadesse S, Mekuria E, Addisu A, Genetu M Prevalence of Anemia and Associated Factors Among Hospitalized Children Attending the University of Gondar Hospital, Northwest Ethiopia. EJIFCC. 2019;30(1):35-47. Published 2019 Mar 1.

5. Assaf S, Juan C. Stunting and Anemia in Children from Urban Poor Environments in 28 Low and Middle-income Countries: A Metaanalysis of Demographic and Health Survey Data. Nutrients. 2020;12(11):3539. Published 2020 Nov 18. doi:10.3390/nu12113539

6. Balarajan Y, Ramakrishnan U, Ozaltin E, Shankar AH, Subramanian $\mathrm{SV}$. Anaemia in low-income and middle-income countries. Lancet. 2011

7. Stevens GA, Finucane MM, De-Regil LM, Paciorek CJ, Flaxman SR, Branca F, Peña-Rosas JP, Bhutta ZA, Ezzati M; Nutrition Impact Model Study Group (Anaemia). Global, regional, and national trends in haemoglobin concentration and prevalence of total and severe anaemia in children and pregnant and non-pregnant women for 1995-2011: a systematic analysis of population-representative data. Lancet Glob Health. 2013 Jul;1(1):e16-25.

8. Algarin C, Nelson CA, Peirano P, Westerlund A, Reyes S, Lozoff B Iron-deficiency anemia in infancy and poorer cognitive inhibitory control at age 10 years. Developmental Medicine \& Child Neurology. 2013;55:453-458

9. Georgieff MK. Iron assessment to protect the developing brain American Journal of Clinical Nutrition. 2017;106:1588S-93S.

10. Giannuzzi G, Schmidt PJ, Porcu E, Willemin G, Munson KM, Nuttle X Earl R, Chrast J, Hoekzema K, Risso D, Männik K, De Nittis P, Baratz ED; 16p11.2 Consortium, Herault Y, Gao X, Philpott CC, Bernier RA Kutalik Z, Fleming MD, Eichler EE, Reymond A. The Human-Specific BOLA2 Duplication Modifies Iron Homeostasis and Anemia Predisposition in Chromosome 16p11.2 Autism Individuals. Am J Hum Genet. 2019 Nov 7;105(5):947-958.

11. Eryilmaz H, Dowling KF, Huntington FC, Rodriguez-Thompson A Soare TW, Beard LM, Lee H, Blossom JC, Gollub RL, Susser E, Gur RC, Calkins ME, Gur RE, Satterthwaite TD, Roffman JL. Association of Prenatal Exposure to Population-Wide Folic Acid Fortification With Altered Cerebral Cortex Maturation in Youths. JAMA Psychiatry. 2018 Sep 1;75(9):918-928.

12. Akşit S. Çocuklarda büyüme ve gelişme. Editörler; Erkan T, Kutlu T, Satar M, Ünüvar E. Pediatri Esasları, İstanbul: İstanbul Kitabevleri; 2016

13. Karaman S, Karakas Z. Anemik Çocuğa Yaklaşım. Çocuk Dergisi. 2013;13(4):131-7

14. WHO. The global prevalence of anaemia in 2011. Geneva: World Health Organization; 2015; Available from: http://www.who.int/iris/handle/10665/177094. Accesed date: 02/08/2021

15. Salami A, Bahmad HF, Ghssein G, Salloum L, Fakih H (2018) Prevalence of anemia among Lebanese hospitalized children: Risk and $\begin{array}{llll}\text { protective } & \text { factors. } & \text { PLoS } & \text { ONE }\end{array}$ e0201806.https://doi.org/10.1371/journal.pone.0201806
16. Muthusamy BG, Venugopal V, S S. Prevalence of anaemia among the hospitalized children in a rural tertiary care teaching hospital. Int J Contemp Pediatr International Journal of Contemporary Pediatrics. 2017; 4(2):431. https://doi.org/10.18203/2349-3291.ijcp20170683

17. Lanzkowsky P, Lipton JM, Fish JD. Lanzkowsky's manual of pediatric hematology and oncology: academic press; 2016.

18. Hazar HU, Elmali ET. 0-5 Yaş Çocuklarda Anemi Değerlendirmesi ve Ebenin Sorumlulukları. Adnan Menderes Üniversitesi Sağlık Bilimleri Fakültesi Dergisi.4(2):171-82

19. Zuffo CRK, Osório MM, Taconeli CA, Schmidt ST, da Silva BHC Almeida CCB. Prevalence and risk factors of anemia in children. Jornal de Pediatria (Versão em Português). 2016;92(4):353-60.

20. Sayar EH, Orhaner BB, Sayar E, NesrinTuran F, Küçük M. Yenidogan ve sut cocuklugu doneminde B 12 vitamini, demir, folik asit eksikliginin sikligi ve maternal duzeylerle iliskisi/The frequency of vitamin B12, iron, and folic acid deficiency in the neonatal period and infancy, and the relationship with maternal levels. Turkish Pediatrics Archive. 2020;55:139-49.

21. Dugdale M. Anemia. Obstet Gynecol Clin North Am 2001;28(2):36381

22. Tezic T, Gedik Y, Kumandas S. Trabzon merkez ve koylerindeki 12-17 yas grubu demir eksikligi prevalansi. Cocuk Sagligi ve Hastaliklari Dergisi 1990;33:209-18. (In Turkish)

23. Dos Santos RF, Gonzalez ES, de Albuquerque EC, de Arruda IK, Diniz Ada S, Figueroa JN, Pereira AP. Prevalence of anemia in under fiveyear-old children in a children's hospital in Recife, Brazil. Rev Bras Hematol Hemoter. 2011;33(2):100-4.

24. Isık Balcı Y, Karabulut A, Gurses D, Ethem Covut I. Prevalence and Risk Factors of Anemia among Adolescents in Denizli, Turkey. Iran J Pediatr. 2012;22(1):77 81

25. Yavuz T, Korkut S, Yavuz O, Kocabay K. Prevalence of anemia and iron deficiency anemia among adolescents in the western black sea region. T Klin J Pediatr 2004;13:71-5.

26. Cetinkaya F, Yildirmak Y, Kutluk G. Severe iron-deficiency anemia among hospitalized young children in an urban hospital. Pediatr Hematol Oncol. 2005 Jan-Feb;22(1):77-81

27. Naiboglu E, Naiboglu S, Turan E, Hatipoglu SS, Akkus CH. Cocuk Servisinde Yatan Hastaların Demir Eksikliği Anemisi Açısından Araştırılması. Medical Journal of Bakirkoy. 2019;15(3).

28. https://hsgm.saglik.gov.tr/depo/birimler/cocuk_ergen_db/dokumanlar/D EMR_GB_TRKYE_PROGRAMI_UYGULAMA_REHBER.pdf

29. https://hsgm.saglik.gov.tr/depo/birimler/cocuk_ergen_db/dokumanlar/y ayinlar/Kitaplar/Bebek_Cocuk_Ergen_Izlem_Protokolleri_2018.pdf

30. Dag H, Ozberk Koc M, Dikker O, Dursun H. Vitamin B12 Serum Levels of Six to Nine-monthold Infants According to Feeding Practices. J Pediatr Res 2020;7:1-6.

31. Stabler SP, Allen RH. Vitamin B12 deficiency as a worldwide problem. Annu Rev Nutr. 2004;24:299-326.

Copyright (C) 2021 The Author(s); This is an open-access article distributed under the terms of the Creative Commons Attribution License (http://creativecommons.org/licenses/by/4.0), (CC BY NC) which permits unrestricted use, distribution, and reproduction in any medium, provided the original work is properly cited. International Journal of Medical Science and Discovery. 